\title{
Study on the change of organic matter along the Processes of Drinking Water Plant
}

\author{
Shuo Zhang* and Ruhua Wang \\ Shanghai Municipal Engineering Design Institute (Group) Co.Ltd., 200092 Shanghai, P.R.China
}

\begin{abstract}
Abstract. According to contaminated raw water and drinking water purification processes, volatile/semi-volatile organic compounds in water are determined by GC-MS. The changes of the organic along the process and water quality from unsafe to safe process were revealed. The results show that there are odorous substances such as heptanal in raw water, which are not detected after the filtration. The composition of volatile organic compounds changes a lot after the ozone activated carbon process, thus anthropogenic pollutants are no longer detected such as 5-ethyl-5-(3-hydroxy isopentyl)-barbituric acid. However, biological metabolites that are not present in raw water such as cedrenol appear. Except disinfection by-products after disinfection, there are a variety of halogenated compounds as 1-1-dichlorocyclobutane and 1-chloro-3,3-dimethyl-butane. Some hydrocarbons and alcohols in the finished water have little impact on drinking water safety.
\end{abstract}

\section{Introduction}

Raw water contains various organic substances, many of which have an adverse effect on human health, such as 2-methylisoborneol (MIB) and Geosmin (GSM) [1,2]. The American Water Works Association surveyed of 388 water companies across the country in 1998. The results showed that 63 persents of water plants had problems with GSM [3]. In the summer of 2007, the smell of drinking water in Saxony, Germany was particularly serious. The measured geosmin and dimethylisoborn were as high as $46 \mathrm{ng} / \mathrm{L}$ and $58 \mathrm{ng} / \mathrm{L}$, which could not be effectively removed by conventional treatment [4]. There were smell problems in Switzerland, Canada, and the UK.

In addition to the odor of the water source, the water pipelines and treatment structures such as open-air sedimentation tanks and reaction tanks are also prone to odor pollution, resulting in a decline in the quality of the finishd water. High concentrations of odorant substances can affect the human respiratory and nervous systems, irritating the body's sense of smell and taste, causing difficulty in breathing, headaches or upset stomach.

In the water plant, each treatment process removes organic matter. Because of the different effects of physical chemistry and biodegradation, organic matter changes along the process. Studying the law of change is conducive to optimizing the process and controlling the safety of drinking water.

\section{Experiment method}

Volatile/semi-volatile organic compounds in water were extracted of by solid phase microextraction (SPME), then adsorbed by GC-MS.

Scanning ionized ions ranging from 40 to 350 molecular weights was used to characterize the relative content of volatile organic compounds with molecular weights below 400 .

\subsection{Sample pretreatment}

Fifteen grams of $\mathrm{NaCl}$ were accurately weighed into a $50 \mathrm{~mL}$ glass bottle with an electronic balance. Then $50 \mathrm{~mL}$ of water sample to be tested were accurately measured which mixing with $\mathrm{NaCl}$ in a glass bottle. The uniformly mixed water sample was placed in a $65^{\circ} \mathrm{C}$ stable controlled water bath and stirred continuously with a magnetic stirrer.

The solid phase micro-extraction needle was fixed above the vortex formed by the stirring of the water sample. The extraction needle was taken out after extraction in a constant temperature water bath at $65^{\circ} \mathrm{C}$ for 30 minutes. The solid phase micro-extraction needle was mainly made by siloxane organic matter as the extraction fixative, which skeleton was the phenolic resin.

\subsection{GC-MS test conditions}

GC-MS QP2010S was manufactured by Shimadzu Corporation, Japan. The column was a capillary column RTX-5 MS.

\footnotetext{
* Corresponding author: zhangshuo@smedi.com
} 
Table 1. Test Conditions of GC-MS.

\begin{tabular}{|c|c|}
\hline Index & Value \\
\hline Gas type & Helium \\
\hline Gas flow rate & $40 \mathrm{~mL} / \mathrm{min}$ \\
\hline Inlet temperature & $250{ }^{\circ} \mathrm{C}$ \\
\hline Inlet pressure & $94.7 \mathrm{kPa}$ \\
\hline Warming procedure & $\begin{array}{r}\text { min; rise to } 210^{\circ} \mathrm{C} \text { at } 10^{\circ} \mathrm{C} / \mathrm{min} ; \\
\text { rise to } 250{ }^{\circ} \mathrm{C} \text { at } 40^{\circ} \mathrm{C} / \mathrm{min} ; \\
250{ }^{\circ} \mathrm{C} \text { for } 2 \text { min }\end{array}$ \\
\hline Ms type & Ionization detector \\
\hline Injection temperature & \multicolumn{2}{|c|}{$200^{\circ} \mathrm{C}$} \\
\hline source temperature & $250{ }^{\circ} \mathrm{C}$ \\
\hline
\end{tabular}

\section{Results and discussion}

\subsection{Raw water}

Hydrocarbons accounted for $34.21 \%$ and most of the fourteen hydrocarbons are alkanes. Alkanes are mainly chain hydrocarbons with short chain branches (such as methyl, ethyl), the main chain is mostly heptane, pentane and decane, and the long chain includes undecane and decane.

The organic matter containing nitrogen, sulfur and phosphorus is the second largest organic substance in raw water, accounting for $28.99 \%$. These substances are complex and often contain benzene rings or other heterocyclic rings. The raw water contains pyrans, furazan, piperidines, quinolines, thiophenes, imidazoles and amides. A raw drug substance, barbituric acid, which can be used as a sedative and a hypnotic agent, has a peak area of 273496 .

There are not many alcohols and ketones in raw water and no aldehydes. Most of the alcohols are longchain pentanol, heptanol, etc., which may be derived from biological metabolism. Among the ketones, there are both suspected natural metabolites, ionones, and possibly artificial pollutants, phenheptone.

The natural biological metabolites account for about $10 \%$, such as heptanal, menthol and adenine,indicating that the water body is seriously affected by biological pollution. The small molecular substances of this kind of biological metabolism mainly include terpenoids, terpenoids, pyrimidines. Odor compounds account for the majority, including the typical odorant heptaldehyde.
Table 2. Distribution of organic in raw water.

\begin{tabular}{|c|c|c|c|}
\hline Organic & Kind & $\begin{array}{c}\text { Sum of } \\
\text { peak areas }\end{array}$ & Removal \\
\hline Alkanes, olefins & 14 & 4892256 & $34.21 \%$ \\
\hline Alcohols, ketones & 8 & 990449 & $6.93 \%$ \\
\hline $\begin{array}{c}\text { Biological } \\
\text { metabolism small } \\
\text { molecules }\end{array}$ & 5 & 1536724 & $10.75 \%$ \\
\hline Esters & 6 & 2119193 & $14.82 \%$ \\
\hline $\begin{array}{c}\text { Halogenated } \\
\text { organics }\end{array}$ & 5 & 365923 & $2.56 \%$ \\
\hline $\begin{array}{c}\text { Polycyclic } \\
\text { aromatic } \\
\text { hydrocarbons }\end{array}$ & 3 & 250164 & $1.75 \%$ \\
\hline $\begin{array}{c}\text { Nitrogen, sulfur, } \\
\text { phosphorus and } \\
\text { other heterocyclics }\end{array}$ & 18 & 4145082 & $28.99 \%$ \\
\hline
\end{tabular}

\subsection{Effluent of sedimentation}

Coagulation and sedimentation have good removal effect on medium and large molecular weight hydrophobic substances and excellent removal effect on esters, polycyclic aromatic hydrocarbons and alcohols. There is the release of biological metabolites, because the response peak area of heptanal increased to 1.5 times and anthraquinones such as sandalwood appear.

Table 3. Distribution of organic in effluent of sedimentation.

\begin{tabular}{|c|c|c|c|}
\hline Organic & Kind & $\begin{array}{c}\text { Sum of } \\
\text { peak areas }\end{array}$ & Removal \\
\hline Alkanes, olefins & 12 & 4454424 & $1.95 \%$ \\
\hline Alcohols, ketones & 6 & 537783 & $25.89 \%$ \\
\hline $\begin{array}{c}\text { Biological } \\
\text { metabolism small } \\
\text { molecules }\end{array}$ & 3 & 849615 & - \\
\hline Esters & 6 & 1507099 & $29.00 \%$ \\
\hline $\begin{array}{c}\text { Halogenated } \\
\text { organics }\end{array}$ & 5 & 306987 & $0.66 \%$ \\
\hline $\begin{array}{c}\text { Polycyclic } \\
\text { aromatic } \\
\text { hydrocarbons }\end{array}$ & 2 & 144362 & $17.72 \%$ \\
\hline $\begin{array}{c}\text { Nitrogen, sulfur, } \\
\text { phosphorus and } \\
\text { other heterocyclics }\end{array}$ & 12 & 2861123 & $7.63 \%$ \\
\hline
\end{tabular}

\subsection{Effluent of ceramsite filter}

The ceramsite biofilter has a good removal effect on the volatile/semi-volatile organic matter in the raw water. The overall removal rate can reach $21.97 \%$, and the species also drops to 48 species. Hydrocarbons are almost not removed. Ketones and alcohols are greatly reduced, especially ketones. The ceramsite filter has 
almost only alcohols in the effluent. The biological small molecular species were not detected except for heptaldehyde, and the bio-ceramic filter itself did not seem to release a large amount of intracellular extracellular substances. Complex benzene-containing rings and nitrogen-containing sulphur-containing organic compounds are good removed, but thiophenes, imidazoles, amides, piperidines and barbituric acid still exist which are difficult to biotransform.

Table 4. Distribution of organic in effluent of ceramsite filter.

\begin{tabular}{|c|c|c|c|}
\hline Organic & Kind & $\begin{array}{c}\text { Sum of } \\
\text { peak areas }\end{array}$ & Removal \\
\hline Alkanes, olefins & 12 & 4542846 & $7.14 \%$ \\
\hline Alcohols, ketones & 7 & 725675 & $26.73 \%$ \\
\hline $\begin{array}{c}\text { Biological } \\
\text { metabolism small } \\
\text { molecules }\end{array}$ & 1 & 184522 & $87.99 \%$ \\
\hline Esters & 8 & 2122705 & - \\
\hline $\begin{array}{c}\text { Halogenated } \\
\text { organics }\end{array}$ & 5 & 309018 & $15.55 \%$ \\
\hline $\begin{array}{c}\text { Polycyclic } \\
\text { aromatic } \\
\text { hydrocarbons }\end{array}$ & 2 & 175450 & $29.86 \%$ \\
\hline $\begin{array}{c}\text { Nitrogen, sulfur, } \\
\text { phosphorus and } \\
\text { other heterocyclics }\end{array}$ & 13 & 3097441 & $25.27 \%$ \\
\hline
\end{tabular}

\subsection{Effluent of granular activated carbon filter}

The effect of activated carbon treatment on the removal of volatile/semi-volatile small molecules is obvious. Due to the action of oxidation, alkanes and olefins in water are substantially free of linear hydrocarbons, and most of them have short chain branches with methyl or ethyl groups. The removal rate of alcohols, ketones and esters is as high as $70 \%$ or more and there are only organic alcohols in the. effluent. Some artificial pollutants, such as 5-ethyl-5-(3-hydroxyisopentyl)-barbituric acid, 2ethoxy-N'-[(Z)-1-phenylethylidene benzene Formyl hydrazide, etc. not detected.

Organic substances with benzene ring and azophos are obviously removed. The overall removal effect is 43.72\%. Among these substances, substances with groups such as pyran, furazan and piperidine are obviously reduced, and some oxygen-containing heterocyclic rings are present. There are biological metabolites different from raw water, such as cedar enol, which are almost non-toxic and have no strong odor and thus affect water acceptability.

Table 5. Distribution of organic in effluent of GAC.

\begin{tabular}{|c|c|c|c|}
\hline Organic & Kind & $\begin{array}{c}\text { Sum of } \\
\text { peak areas }\end{array}$ & Removal \\
\hline Alkanes, olefins & 9 & 2877475 & $33.29 \%$ \\
\hline
\end{tabular}

\begin{tabular}{|c|c|c|c|}
\hline Alcohols, ketones & 3 & 159483 & $72.98 \%$ \\
\hline $\begin{array}{c}\text { Biological } \\
\text { metabolism small } \\
\text { molecules }\end{array}$ & 2 & 154525 & - \\
\hline Esters & 3 & 279949 & $78.36 \%$ \\
\hline $\begin{array}{c}\text { Halogenated } \\
\text { organics }\end{array}$ & 2 & 133843 & $55.35 \%$ \\
\hline $\begin{array}{c}\text { Polycyclic } \\
\text { aromatic } \\
\text { hydrocarbons }\end{array}$ & 0 & 0 & - \\
\hline $\begin{array}{c}\text { Nitrogen, sulfur, } \\
\text { phosphorus and } \\
\text { other heterocyclics }\end{array}$ & 10 & 1546559 & $43.72 \%$ \\
\hline
\end{tabular}

\subsection{Effluent of post-sand filer}

The post-sand filtration process has little effect on the overall removal of organic matter. As a guarantee against bio-leakage, the two biological metabolites detected in the carbon effluent have been removed.

Table 6. Distribution of organic matter in effluent of post-sand filer.

\begin{tabular}{|c|c|c|c|}
\hline Organic & Kind & $\begin{array}{c}\text { Sum of } \\
\text { peak areas }\end{array}$ & Removal \\
\hline Alkanes, olefins & 9 & 2819624 & $2.01 \%$ \\
\hline Alcohols, ketones & 3 & 156172 & $2.08 \%$ \\
\hline $\begin{array}{c}\text { Biological } \\
\text { metabolism small } \\
\text { molecules }\end{array}$ & 0 & 0 & - \\
\hline Esters & 3 & 287973 & 0 \\
\hline $\begin{array}{c}\text { Halogenated } \\
\text { organics }\end{array}$ & 2 & 135623 & 0 \\
\hline $\begin{array}{c}\text { Polycyclic } \\
\text { aromatic } \\
\text { hydrocarbons }\end{array}$ & 0 & 0 & 0 \\
\hline $\begin{array}{c}\text { Nitrogen, sulfur, } \\
\text { phosphorus and } \\
\text { other heterocyclics }\end{array}$ & 10 & 1501246 & $2.93 \%$ \\
\hline
\end{tabular}

\subsection{Finished water}

Chlorination disinfection complicates the organic composition of the factory water. Volatile/semi-volatile organic compounds have increased significantly, especially halogenated organics, which are 20 times more than the post-sand effluent, 7 times that of raw water, with typical disinfection by-products such as tribromomethane and dibromonitromethane. The oxidation of the disinfectant causes the organic matter in the water to be converted from macromolecules to volatile small molecules, producing some volatile organic compounds that are not present in the water, resulting in 48 kinds of organic matter in the factory water. The total amount of volatile organic compounds is also greatly increased, and the peak area is twice that of 
the post-sand effluent. Except for disinfection byproducts, there are no other substances that are clearly harmful to the human body. Some hydrocarbons and alcohols still exist in the finished water, but these substances have little effect on drinking water safety.

Table 7. Distribution of organic matter in finished water.

\begin{tabular}{|c|c|c|c|}
\hline Organic & Kind & $\begin{array}{c}\text { Sum of } \\
\text { peak areas }\end{array}$ & Removal \\
\hline Alkanes, olefins & 10 & 3120418 & $30.72 \%$ \\
\hline Alcohols, ketones & 7 & 890778 & $8.77 \%$ \\
\hline $\begin{array}{c}\text { Biological } \\
\text { metabolism small } \\
\text { molecules }\end{array}$ & 0 & 0 & 0 \\
\hline Esters & 8 & 695699 & $6.85 \%$ \\
\hline $\begin{array}{c}\text { Halogenated } \\
\text { organics }\end{array}$ & 11 & 2785944 & $27.42 \%$ \\
\hline $\begin{array}{c}\text { Polycyclic } \\
\text { aromatic } \\
\text { hydrocarbons }\end{array}$ & 0 & 0 & 0 \\
\hline $\begin{array}{c}\text { Nitrogen, sulfur, } \\
\text { phosphorus and } \\
\text { other heterocyclics }\end{array}$ & 12 & 2665763 & $26.24 \%$ \\
\hline
\end{tabular}

\subsection{Odor substance}

The concentration of odor substances in raw water is higher than heptaldehyde and dimethyl isobornyl. After the overall process, the concentration of odorant substances in the finished water is lower than the odor threshold. The factory water heptaldehyde concentration is only $3.34 \mathrm{ng} / \mathrm{L}$ and the removal rate is as high as $92 \%$. The concentration of dimethyl isobornyl is only 1.59 $\mathrm{ng} / \mathrm{L}$ and the removal rate is as high as $92 \%$. The odorant substance is mainly removed by deep processing, accounting for more than $80 \%$. The conventional and biological filtration combination process can remove heptaldehyde about $16 \%$, the removal amount is $6.5 \mathrm{ng} / \mathrm{L}$. The removal rate of dimethyl isobornyl is about $5 \%$, and the removal amount is $1 \mathrm{ng} / \mathrm{L}$. The removal rate of heptaldehyde from ozone activated carbon was about $90 \%$, the removal amount was $30 \mathrm{ng} / \mathrm{L}$, the removal rate of dimethyl isobornyl was about $91 \%$, and the removal amount was $16.7 \mathrm{ng} / \mathrm{L}$.

Table 8. Removal of odor substance (ng/L).

\begin{tabular}{|c|c|c|c|}
\hline Organic & $\begin{array}{c}\text { Raw } \\
\text { water }\end{array}$ & $\begin{array}{c}\text { Effluent of } \\
\text { ceramsite } \\
\text { filter }\end{array}$ & $\begin{array}{c}\text { Finished } \\
\text { water }\end{array}$ \\
\hline Heptanal & 39.74 & 36.24 & 33.21 \\
\hline 2-Methylisoborneol & 19.25 & 18.72 & 18.26 \\
\hline Geosmin & ND & ND & ND \\
\hline Dimethyltrisulfide & 8.85 & 5.21 & ND \\
\hline
\end{tabular}

\section{Conclusion}

There are typical biological metabolites in the raw water such as heptanal. After the ozone activated carbon process, the human pollutants are removed and the ester compounds are increased. After chlorination, disinfection by-products such as tribromomethane appear. Some hydrocarbons and alcohols are present in the finished water.

\section{Acknowledgments}

The authors would like to acknowledge the financial support by the key Special Program on the S\&T for the Pollution Control and Treatment of Water Bodies (No.2017ZX07501001-05) and the Shanghai Science and Technology Committee Program (No.16DZ0503500).

\section{References}

1. G. Izaguirre, Wat. Sci. \& Tech, ,25,2(1992)

2. G . Izaguirre, W. D. Taylor.Wat. Res, 32,5(1998)

3. G . Dussert, Wat. Res, 31,5(1997)

4. K. Kutschera, Wat. Res,43(2009)

5. H. H. Xie, N. Y. Gao, N. An, K. J. Zhang, Y. C. Shen, S. X. Wang, Wat \& Wast Eng.38,1(2012) 